Arch. histol. jap., Vol. 44, No. 3 (1981) p. $285-297$

\title{
Three-Dimensional Structure of Tomes' Processes and Enamel Prism Formation in the Kitten
}

\author{
Minoru Wakita, Hiroshi Tsuchiya, Takahide Gunj and Shigeo Kobayashi \\ Department of Oral Anatomy II (Prof. S. Koвayashi), Niigata University School of Dentistry, \\ Niigata, Japan
}

Received December 19, 1980

\begin{abstract}
Summary. The Tomes' processes of ameloblasts in the kitten were examined with both transmission and scanning electron microscopes and their three-dimensional structure demonstrated. In general, Tomes' process can be envisaged as the upper part of a diagonally cut column. It was established that the flat crescent face of the process which is slanted cervically, is the secretory surface (S-face) and the curved crescent surface which is cuspally directed, is the nonsecretory surface ( $\mathrm{N}$-face). The cervical border of the $\mathrm{S}$ face is confluent with the free apical surfaces of cervically adjacent ameloblasts. Only the S-face and the adjoining small part of the next ameloblasts produce enamel and arrange crystallites into prisms as evidenced by the perpendicular orientation of crystallites to the S-face of Tomes' process and the free ameloblast surface. Crystallite arrangement within prisms and prism arrangement within enamel are determined by the three-dimensional morphology of the Tomes' processes. The processes are schematically represented and their relationship to other ultrastructural features as seen in sections is discussed.
\end{abstract}

The pattern of cross-sectioned enamel prisms varies from species to species of mammals, a property which has been used as a taxonomic criterion (SHOBUZAw A, 1952; Fujita, 1957; Boyde, 1965, 1971; Poole, 1971). Prism orientation in enamel is closely related to the shape and orientation of the apical processes of the ameloblasts, the Tomes' processes which lie directly below the layer of developing enamel. BoydE (1967) characterized the relationship by saying that prism orientation represents the fossilized path traced by the Tomes' processes during enamel secretion.

Each prism is composed of closely packed apatite crystallites with a certain regular arrangement. This arrangement has been investigated with X-ray diffraction methods (BAle et al., 1934; Poole and Brooks, 1961) and with the light microscope, particularly by using polarized light (Schmidt, 1937; Lyon and DarLing, 1957). Since Gerould (1944) examined tooth enamel in silicate replicas and FeArnhead (1960) studied ultrathin enamel sections electron microscopically, this subject has attracted the interest of numerous investigators, particularly those working with electron microscopes (Lenz, 1958; Frank and Sognnaes, 1960; Rönnholm, 1962; Helmcke et al., 1963; Meckel et al., 1965a, b; Boyde, 1967; Helmcke, 1967; Kirino et al., 1972; Weber and GLICK, 1975). 
Some of these reports schematically represent crystallite arrangement in prisms (Poole and Brooks, 1961; Boyde 1965, 1967). Above all, Boyde $(1965,1967)$ attempted to illustrate the relationship between the Tomes' processes and the orientation of crystallites in a prism. He proposed a factor controling crystallite arrangement: the crystallites tend to be oriented perpendicular to the mineralizing front. This is a very useful approach. However, crystallites in prisms do not always appear oriented perpendicular to the membrane of the Tomes' processes, especially in the tail region of keyhole-shaped prisms. Boyde (1965) interpreted this to be the result of the "stroking effect" exerted by the ameloblasts that move from the dentine-enamel junction to the future enamel surface. It is necessary to demonstrate precisely the three dimensional structure of Tomes' processes in order to substantiate BoyDE's interpretation and to understand amelogenesis from this point of view (KALLENBACH, 1977). With this in mind, Boyde (1967) and KALLENBACH (1977) attempted to reconstruct the three-dimensional aspect of Tomes' processes from extremely obliquely sectioned material for electron microscopy. SkoвE recently demonstrated Tomes' processes in the rat (1976) and the monkey (1977) with the scanning electron microscope. These studies, however, did not reveal the relationship between crystallite appearence in various prism sections and the shape of the processes producing enamel.

The aim of the present investigation was to examine Tomes' processes with the aid of both transmission and scanning electron microscopy in order to better understand the shape of the process as it relates to the arrangement of crystallites in enamel prisms. The kitten was selected as the material because amelogenesis in this species is similar to that in man (Allan, 1967; Frank and Nalbandian, 1967; KaLlenBACH, 1977).

\section{MATERIAL AND METHODS}

Two kittens aged two months were uesd for this study. They were perfused with a $0.1 \mathrm{M}$ phosphate buffered solution of $2 \%$ paraformaldehyde and $1.25 \%$ glutaraldehyde at a $\mathrm{pH}$ of 7.3. The jaws were removed and immersed in the same fixative overnight. Permanent tooth germs were dissected out and half of them demineralized in 1-ascorbic acid (Dietrich and Fontaine, 1975) for a week.

For transmission electron microscopy, tooth germs were postfixed in $\mathrm{OsO}_{4}$, dehydrated in ethanol and embedded in Epon 812 or Spurr's resin. Ultrathin sections were prepared with glass knives and examined in a Hitachi HS-11D at $75 \mathrm{kV}$.

For scanning electron microscopy, the enamel organ was gently torn from the developing enamel surface either in buffer solution prior to osmification or in $70 \%$ ethanol subsequent to osmification (SKoвe, 1976, 1977). The soft tissues were dehydrated in acetone, transferred to isoamyl acetate and dried by the critical point method. The specimens were scanned in a Hitachi SSM-2 or S-430 at $20 \mathrm{kV}$. 


\section{RESULTS}

\section{Light and transmission electron microscopy}

Figures $1 a$ and $b$, both taken from the same section trimmed cuspo-cervically, illustrate the appearence of longitudinally sectioned ameloblasts. In one part of the section (Fig. 1a), the Tomes' processes have the triangular shape commonly seen in light microscope sections. In another part (Fig. 1b) in the same section, many have a rectangular contour. They are separated from the rest of the ameloblast by the terminal bar. The inner, granular substance of the processes generally stained less with methylene blue than did the remaining cytoplasm.

One side of the triangularly shaped process is often slightly curved, the other usually straight. The TEM revealed that the ultrastructure of the processes and that of the ameloblasts proper differ distinctly (Fig. 2). The processes do not contain rough endoplasmic reticulum ( $\mathrm{rER}$ ) nor mitochondria. The two regions are clearly separated by the terminal web-terminal bar system. Some structures, however, can be observed on both sides of this system, e. g. round electron-dense bodies of various sizes. There are also membrane-bound structures of different sizes and shapes
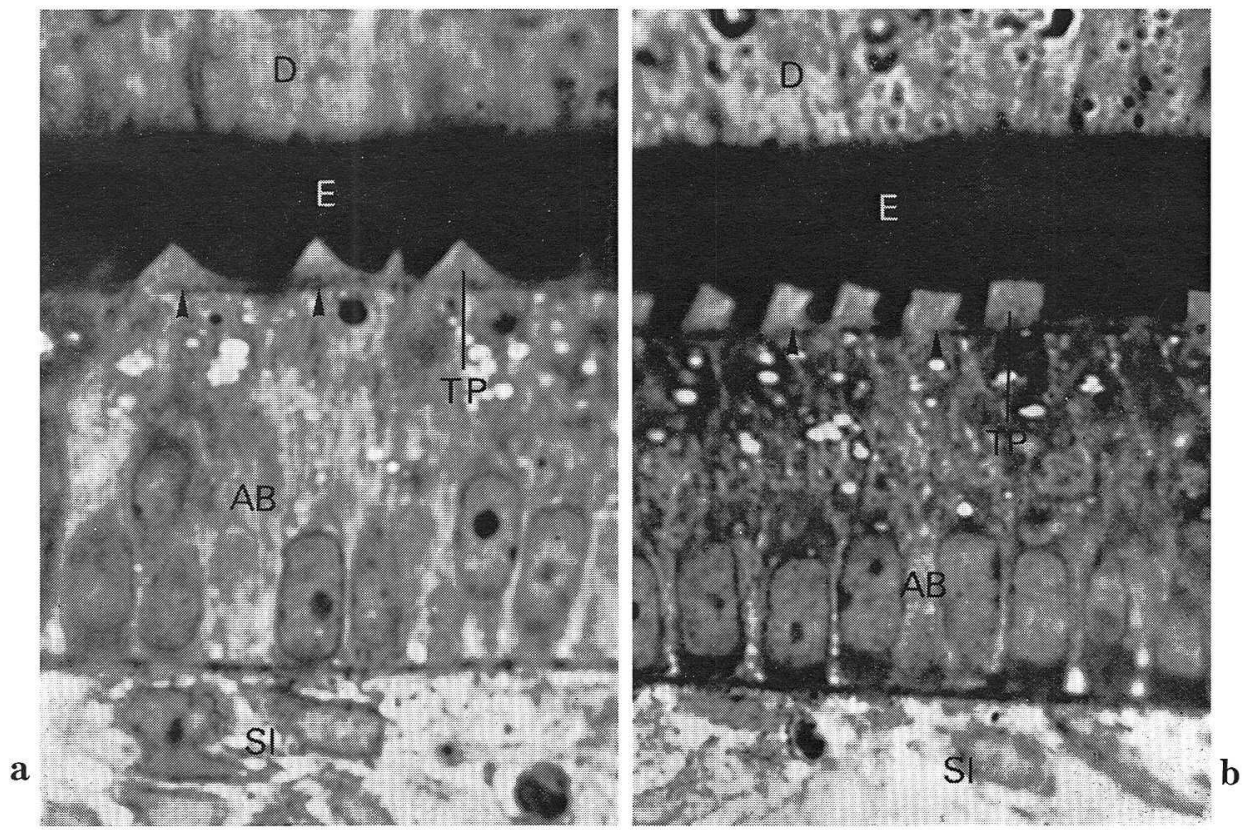

Fig. 1. a and b. Light micrographs from the same section stained with methylene blue and azur II, showing ameloblasts $(A B)$ and 'Tomes' processes $(T P)$ with two different contours, triangular (a) and rectangular (b). Both types of processes are distinctly bordered by apical terminal bars (arrowhead) and dipped in the enamel matrix $(E)$. One of the two faces of each triangular process (a) is slightly curved and the other is straight. The top side of the rectangular process is generally flat, but may occasionally be curved. $D$ dentine, SI stratum intermedium. $\times 1,000$ 
containing stippled material. This material gradually becomes denser from the deeper ameloblast cytoplasm to the surface of Tomes' process. A large amount of stippled material also lies in the intercellular spaces between the ameloblasts. The areas in which much of this is accumlated seem to be connected with the extracellular space via narrow channels or even large openings. The more rectangular processes vary considerably both in length and in width, generally not being as tall as they are wide.

At the surface of the Tomes' process the crystallites, which appeared as slender, light spaces after demineralization, are usually arranged perpendicularly to the cell surface and parallel to each other. Where the membrane of the process curves slightly, the crystallites follow the curvature and are then no longer parallel to each other. Where the membrane curves more sharply, or is folded, the crystallites do not adhere to this pattern of arrangement. This was shown, for example, on the side on which the vesicles of stippled material opened to the extracellular space.

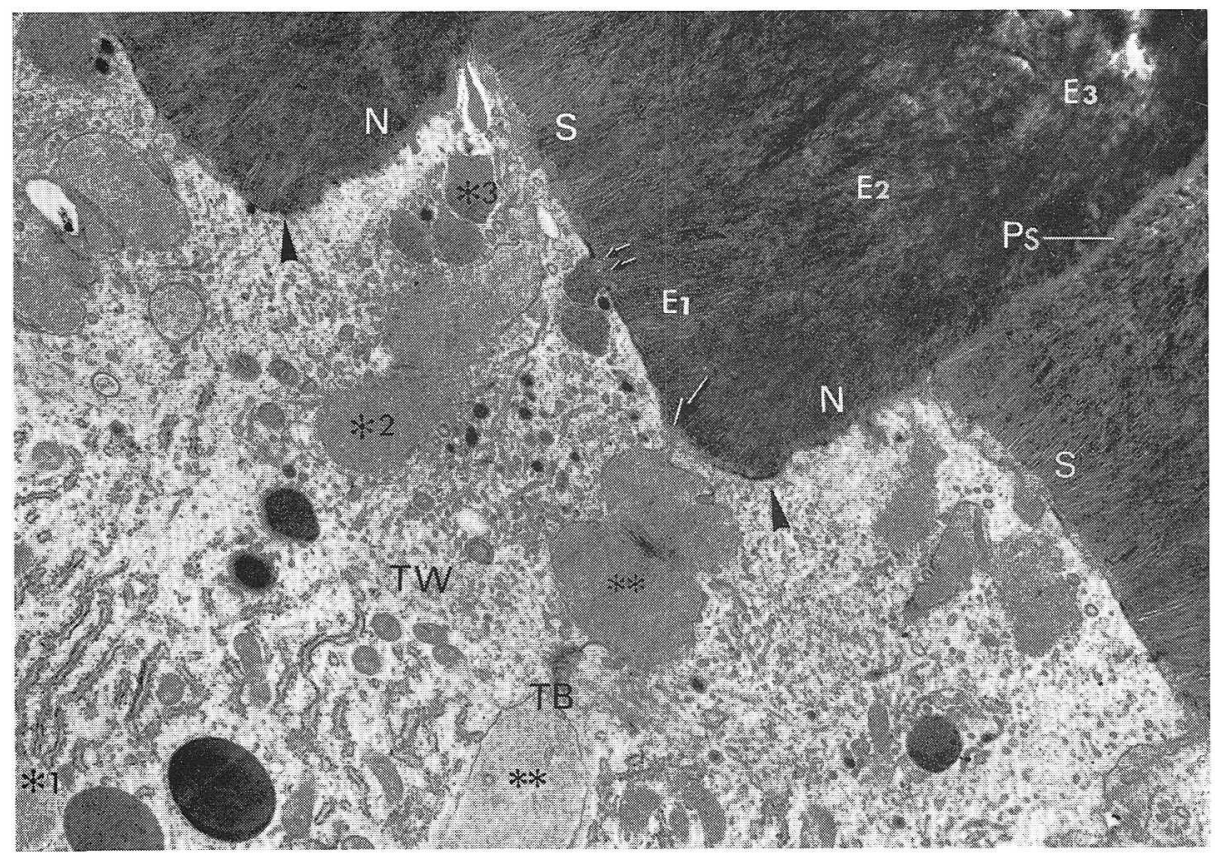

Fig. 2. Transmission electron micrograph of Tomes' processes showing triangular contour. Enamel crystallites are arranged perpendicularly to the S-face (S), but not to the $\mathrm{N}$-face $(N)$. Crystallite inclination at the $\mathrm{N}$-face is like that at the base of the $\mathrm{N}$-face next to the half-desmosome (arrowhead). Stippled material is shown both in the Tomes' processes (asterisk) and in intercellular space (double asterisk). Such areas are continuous with the extracellular space-the enamel matrix-by narrow channels (arrow) or large openings (double arrow). They show increasing electron density from the inner part of the ameloblast to near the surface of the process (asterisk 1,2 to 3). The enamel matrix also shows increasing density from near the cell surface to the deeper portions of the enamel $\left(E_{1}, E_{2}\right.$ to $\left.E_{3}\right)$. Stippled material situated between the cell membrane and the enamel extends from the tip of the process into the deeper portion of the enamel to form the prism sheath $(P s)$. $T B$ terminal bar, $T W$ terminal web. $\times 5,000$ 
Crystallites arranged perpendicularly to the surface can be found only on one side of the triangular process (Fig. 2), namely on the slightly curved, cervically directed surface (cervical side). On this side, many vesicles with stippled material communicate with the extracellular space, strongly suggestive of secretory activity. The cuspally directed side, however, only rarely showed signs of secretion.

The secretory surface of each Tomes' process is continuous with a small, slightly curved portion of the cervically adjacent ameloblast (Fig. 2). The crystallites are also arranged perpendicularly to the surface of this small section of ameloblast. Crystallites arranged perpendicularly to the cell membrane appear only on that part of the surface of the process which extends from its tip to the hemi-desmosome situated at the base of the cervically adjacent process (Fig. 2). Concerning the rectangular process, crystallites can be found only on top of the process itself or on the ameloblast membrane between the processes with perpendicular arrangement to the cell membrane, not on the side wall of the process (Fig. 3).

The electron density of the organic matrix gradually increases from near the cell surface to the deeper parts of the enamel. This was also observed along the cuspal side of the triangular process and along the lateral sides of the rectangular one manifesting itself in a tendency of the material to become darker the further away it was from the cell surface.

Crystallites are inclined in a similar manner both along the steep sides of Tomes' process and at the base of each steep side where the membrane of the process

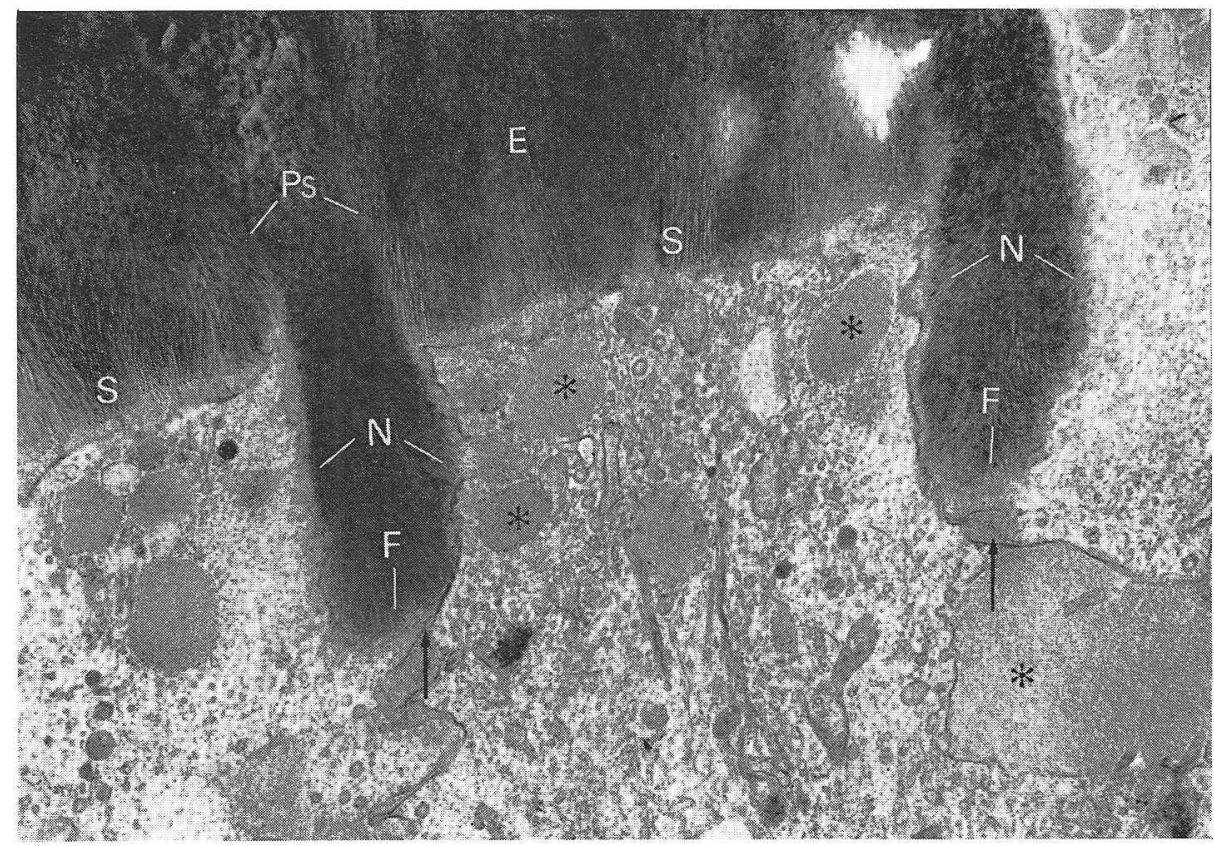

Fig. 3. The rectangular Tomes' process and enamel crystallites oriented perpendicularly to the flat top side of the process and many openings of stippled material (asterisk). Free surfaces of ameloblasts $(F)$ located between the processes are very narrow and stippled material situated between the ameloblasts is continuous with the enamel matrix $(E)$ through the narrow channels (arrow). S S-face, Ps prism sheath. $\quad \times 5,000$ 
continues as that of the ameloblast. It is at this transition that the membrane is curved and the hemidesmosome can be found (Fig. 2, 3).

There is a thin layer containing fine stippled material between the mineralizing front and the cell membrane. This layer continues on between the young enamel prisms and appears as a lightly stained line extending from the tip of each process into the deeper parts of the enamel.

\section{Scanning electron microscopy}

After removing the epithelium from the developing enamel, many small Tomes' processes could be seen on the surface of the epithelium facing into the enamel (Fig. 4). Some of them had been broken off, probably due to mechanical injury during preparation, but others still had a fairly smooth contour. Each process has one relatively flat, cervically directed face (secretory or S-face) and another more curved, cuspally directed face (nonsecretory or N-face) (Fig. 4, 5). These two faces meet at the apex of the process creating its curved ridge-like free edge (Fig. 4, 5). The lower parts of each face and the lateral aspects of the ridges join the ameloblast membrane located between the processes.

The direction in which the S-faces face varies from one group of Tomes' processes to the next (Fig. 8). The inclination of the N-face to the ameloblast cell body was steeper than that of the S-face.

The surface of the S-face is irregular; hollows of various sizes and shapes indent

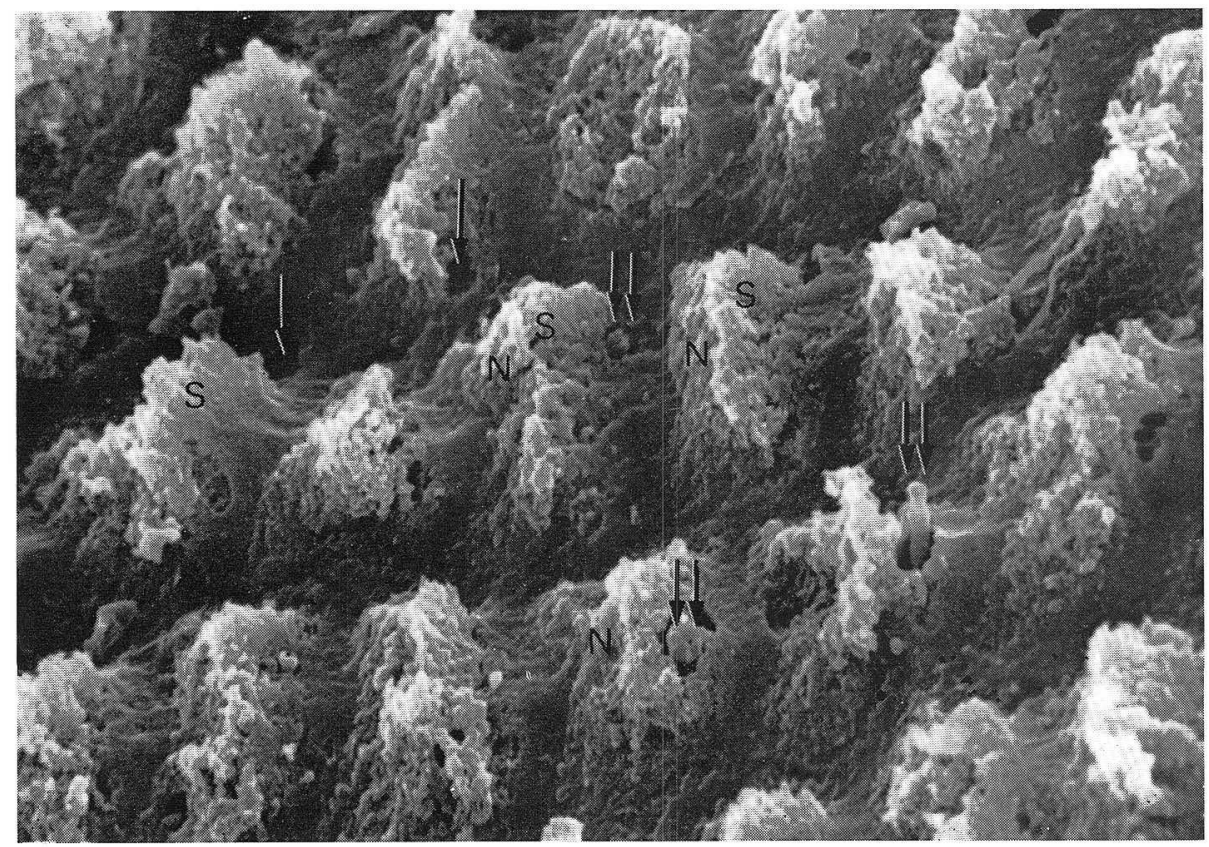

Fig. 4. Scanning electron micrograph showing Tomes' processes with characteristic shapes. Each of them has two faces: one is the flat S-face $(S)$ and the other is the curved $\mathrm{N}$-face $(N)$. Some of the processes were injured, probably during preparation. On the S-face and the free surfaces of ameloblasts many openings of various sizes can be seen (arrow); occasionally secretory substances are observed in some of them (double arrows). $\times 5,000$ 


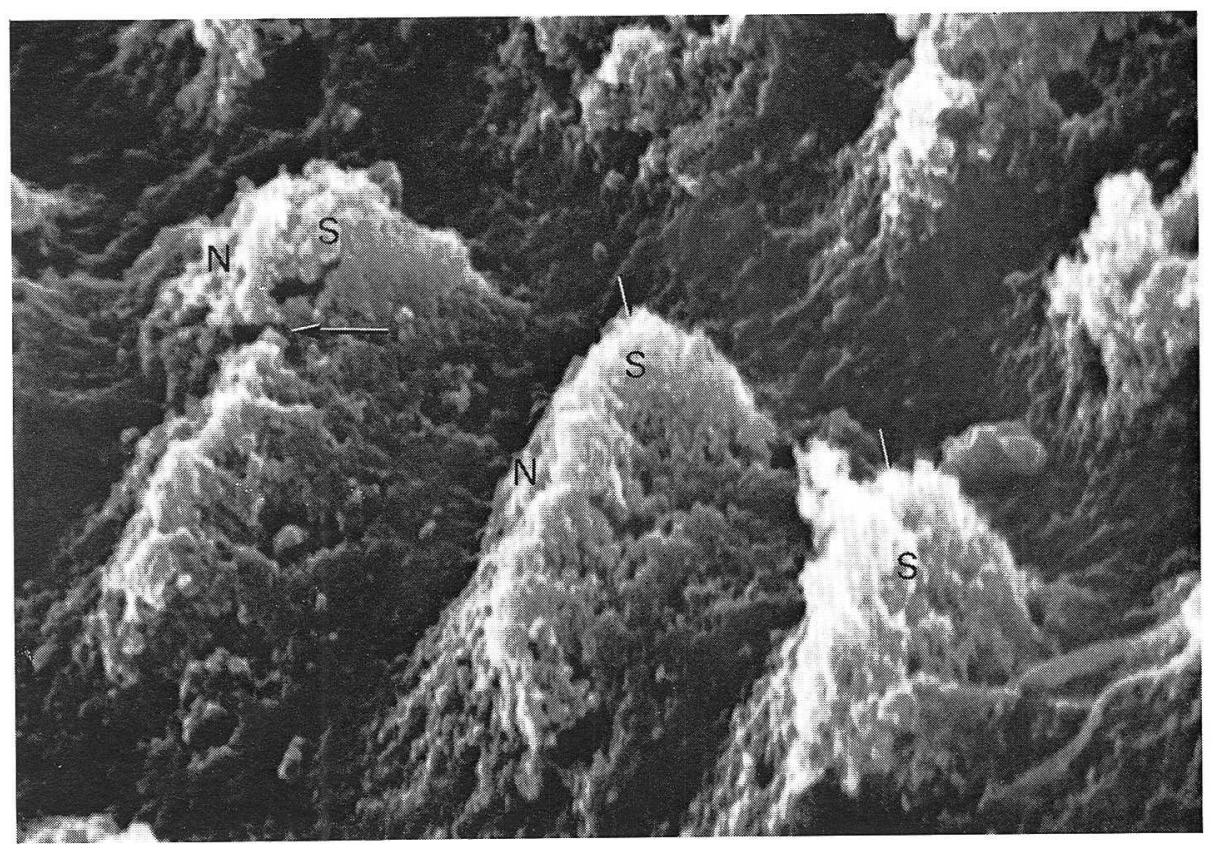

Fig. 5. High power scanning electron micrograph of Tomes' processes showing the flat Sface $(S)$ and the curved $N$-face $(N)$, and the ridge (arrowhead) where the two meet. Sometimes two processes directly adjacent to each other without the interposing free surface of an ameloblast (arrow). In such cases a ridge is continuous with an S-face of the neighboring process. $\times 10,000$

the otherwise smooth surface (Fig. 5). Frequently, round, bulb-like structures could be detected in the larger hollows (Fig. 4-6). In comparison with the S-face, the N-face is fairly rough but it had neither hollows nor bulb-like structures (Fig. 6).

In the areas between the Tomes' processes, occasional large hollows were observed but bulb-like structures were rarely seen (Fig. 4-6). The ridges of the processes were often covered with an amorphous material which concealed the contours of the processes (Fig. 4-6).

In marginal areas of the tooth germ in which the Tomes' processes began to appear and were still growing, the processes looked like small mounds with comparatively large S-faces but small $\mathrm{N}$-faces (Fig. 7). Since the $\mathrm{N}$-face is small, the inclination of the S-face to the adjoining ameloblast surface is not as steep as in the larger Tomes' processes. On the whole, the processes in the marginal areas are considerably smaller than the typical ones in the main regions of enamel production and are consequently separated by larger spaces of free ameloblast surface.

\section{DISCUSSION}

As seen in Figure 5, the Tomes' processes resemble obliquely cut cylinders. The flat, crescent-shaped planes (S-face) face the surface of the developing enamel and are directed cervically and occasionally somewhat laterally in groups. BoydE (1969) and 


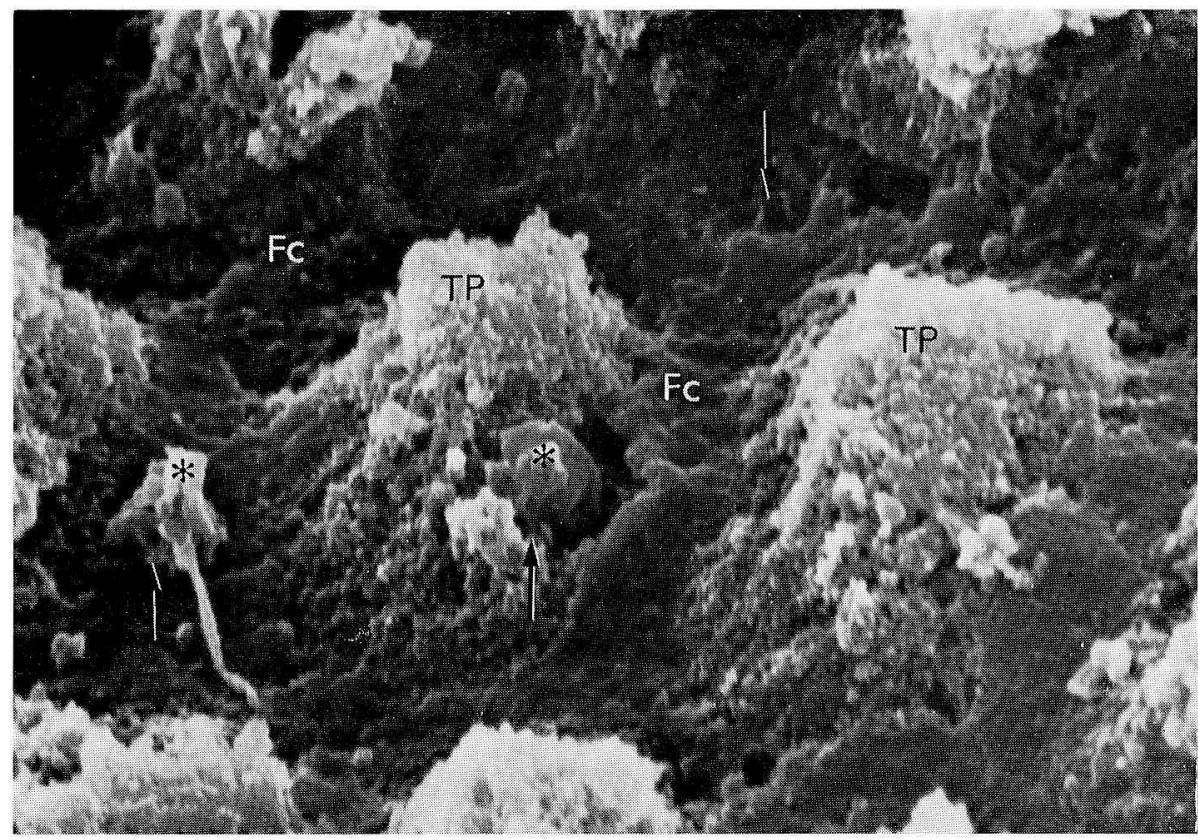

Fig. 6. Scanning electron micrograph showing ameloblasts with Tomes' processes (TP), free surface of ameloblast $(F c)$ and many openings in the cells (arrow). In these openings stippled material (asterisk) appears (compare with Figures 2 and 3). $\quad \times 10,000$
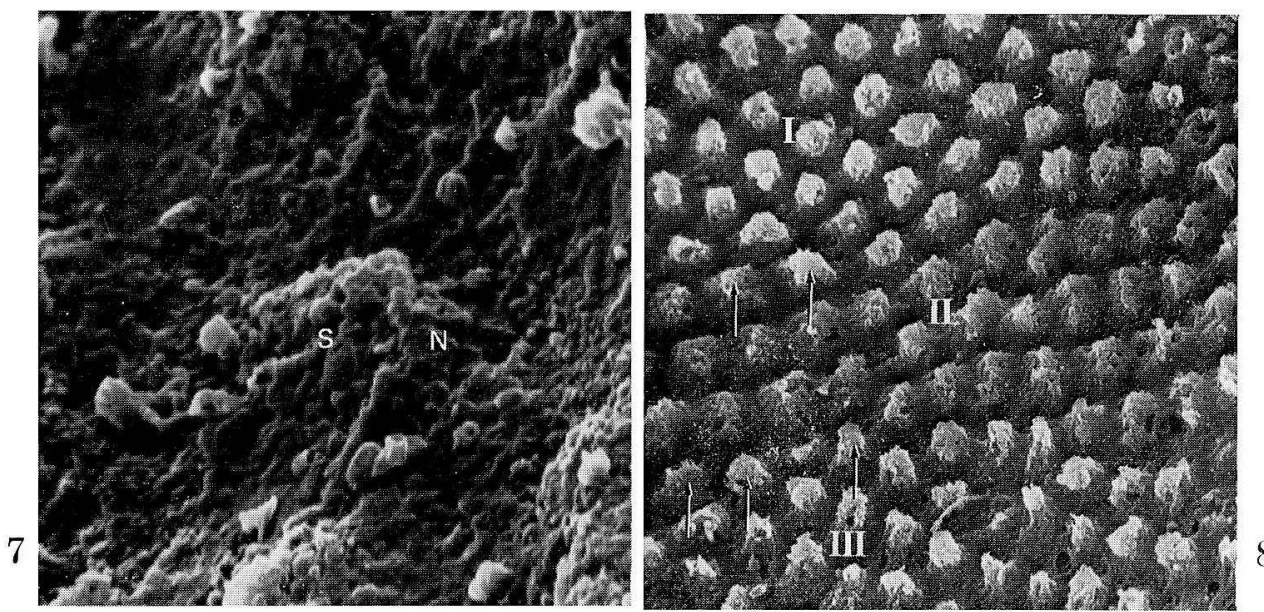

Fig. 7. Scanning electron micrograph showing Tomes' processes in an early stage of secretion with a narrow $\mathrm{N}$-face $(N)$. Therefore the S-face $(S)$ intersects the ameloblast surface at a smaller angle than in the fully developed process and is directed toward the dentine. $\times 10,000$

Fig. 8. Low power scanning electron micrograph showing some groups of Tomes' processes with differently directed S-faces. One group $(I)$ has S-faces directing downwards, another $(I I)$ has S-faces facing to the right, the third again downwards $(I I I)$. Between groups I, II and III there are a few processes with S-faces inclined in yet another direction (arrows). $\times 1,000$. 
Skobe $(1976,1977)$ examined the surface of the developing enamel and reported that enamel is formed at the apical end of the Tomes' processes, i.e., at the bottom of pits from which the Tomes' process had been removed. The inclination of the $\mathrm{N}$-face to the longitudinal axis of the ameloblast coincides with the longitudinal axis of the prism both in the triangular and the rectangular processes (Fig. 2, 3). Boyde (1965) noted that the crystallites tent to be oriented perpendicularly to the mineralizing front. This is a valuable observation. At the same time he also noticed that crystallites in the tail region of keyhole-shaped prisms do not conform to this pattern of arrangement. Boyde proposed that this divergence resulted from the stroking effect exerted by the Tomes' process on the mineralizing front.

We have also observed that the inclination of the crystallites on the $\mathrm{N}$-face is apparently not perpendicular to this surface, but all the crystallites on this surface have the same angle with respect to it. The very same angle appears at the base of the Tomes' process where the free surface of the ameloblast is confluent with the $\mathrm{N}$-face and where the halfdesmosome is located.

Up to now, it has been generally accepted that the enamel prism is formed by the entire surface of the Tomes' process which secrets organic ground substances. However, in view of the present findings, this may no longer apply to the $\mathrm{N}$-face. It would seem impossible that crystallites are formed simultaneously along $\mathrm{N}$-face both near the tip of the process and close to its base. The $\mathrm{N}$-face is parallel to the axis of the prism as a whole. When crystallites are formed at the base of the process, they slide along the $\mathrm{N}$-face and finally pass the tip region of the process as a result of lateral moving of ameloblasts. The crystallites along the $\mathrm{N}$-face should therefore be considered as only passing from the base to the tip of the process. The prism itself is formed by the secretory surface which includes the plane extending from the ridge of the process to the region at the base of the $\mathrm{N}$-face directed cervically where the half-desmosome is located (Fig. 2, 9, 10). The S-face of the present study corresponds to the type- 1 face described

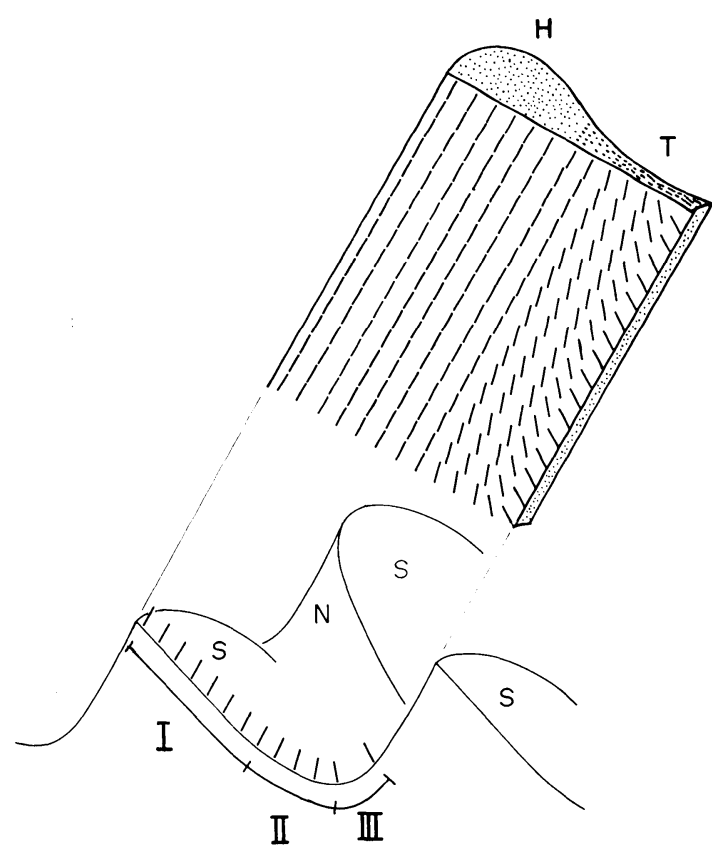

Fig. 9. Schematic drawing of the three dimensional form of Tomes' processes and their relationship to crystallite arrangement in a prism. As a whole, the process looks like a diagonally cut column with a flat surface (S-face: $S$ ) and a curved one (N-face: $N$ ). Crystallites are produced only on the S-face (area I), the free surface of the ameloblast (area II), and in the base region of the cervically adjacent $\mathrm{N}$-face (area III). Since this scheme was constructed on the assumption that the S-face is flat, crystallites in the head region of the prism $(H)$ are arranged parallel to the prism axis. $T$ tail region of the prism. 


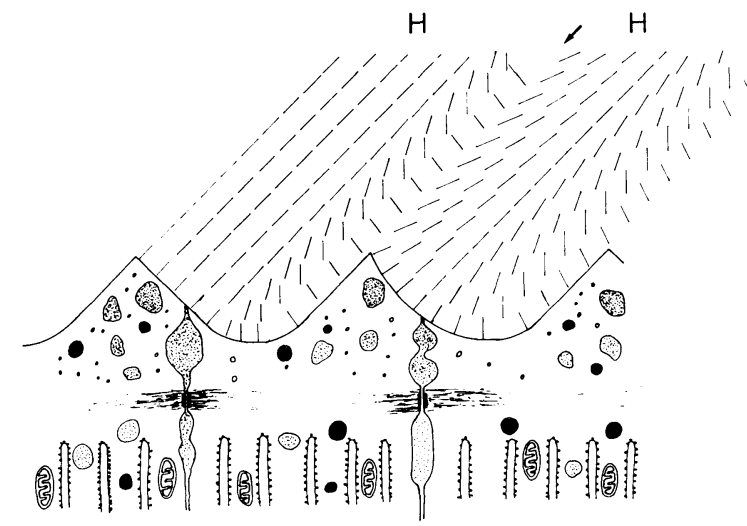

Fig. 10. Diagram of ameloblasts and Tomes' processes with two types of S-faces, flat and concave, and their relationships to crystallite arrangement in prism. As KALlenBACH (1977) showed, the S-face of a Tomes' process is composed of cell membrane from two ameloblasts. Crystallites formed on the flat S-face (left in this figure) are arranged parallel to the prism axis in the head region of the prism $(H)$, just as in Figure 9. On the other hand, crystallites formed on the concave S-face (right) are not arranged parallel to the prism axis, but show a characteristic fanning out from the prism axis. The inclination of crystallite axes along the boundary between prisms (arrow) changes abruptly. lites rotates gradually so that the crystallites above the ameloblast surface are oriented parallel to the axis of the particular ameloblast itself (area II in Fig. 9). The axis rotates further at the cervical extent (area III in Fig. 9) of the S-face. Thus the angle at which the crystallite axis deviates from the prism axis increases from cuspal to cervical. The schematic representations (Fig. 9, 10) depict the relationship between the angle devergence of crystallites in enamel and the corresponding secretory surfaces described in the literature; the arrangement of apatite crystallites along the external portions of a prism or between the prism and the interprismatic substance differs from that in the center of a prism (Helmcke, 1960; Poole and Brooks, 1961; Rönnholm, 1962; Helmcke et al., 1963; Boyde, 1965; Meckel et al., 1965a, b; Helmcke, 1967).

This cuspo-cervical scheme (Fig. 10) suggests that the surface contour of the S-face plays an important role in determining the arrangement of crystallites in the head region of prisms and that the angle of the $\mathrm{N}$-face to the ameloblast surface is also important in determining the angle of inclination of the prisms to the developing enamel surface. In a prism sectioned cuspo-cervically, apatite crystallites fan out from the prism axis in the head region (Poole and BRooks, 1961; Helmcke et al., 1963; Meckel, et al., 1965a, b; HeLmcke, 1967). This characteristic arrangement of crystallites in a prism is due to the concavity of the S-face (compare the prisms in Figure 10).

From this point of view it can be said that the crystallite arrangement in a prism represents the fossilized shape of the Tomes' process during amelogenesis.

The pattern revealed in cross sectioned prisms was classified by BoyDE (1965, 1969). We suggest that the differences seen between pattern 2 and 3 in Boyde's 
A
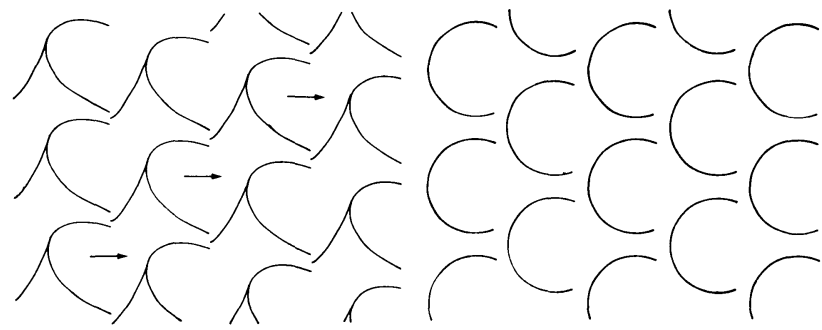

B

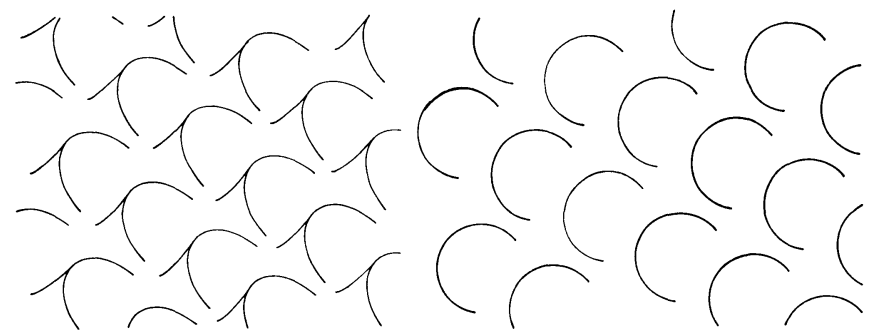

Fig 11. Diagrams showing the relationship between the direction of the Sface of Tomes' processes and the prism pattern which is formed by them. Left and right figures in group $\mathbf{A}$ and $\mathbf{B}$, respectively correspond to each other. Normally, when the S-faces are arranged alternatively, as in group A, then enamel prisms are also found in an alternative position. Each S-face in this group slants (arrow) toward the region between two cervially adjacent processes. The B group was constructed by turning the processes in group A by $45^{\circ}$ clockwise, causing the S-faces of this group to slant strictly toward the adjacent $\mathrm{N}$-face. These processes form a prism pattern with a linear arrangement.

classification might be due to the spacial orientation of the Tomes' processes. Where all S-faces in a given area are directed cervically, the prisms will be arranged alternatively, corresponding to Boyde's pattern 3, and show the typical keyhole shape in cross section. The S-face, however, is not always uniformly cervically directed. Occasionally, within an area of Tomes' processes whose S-face is cervically directed, one can find a group of somewhat laterally oriented processes (Fig. 8). Recently we (W aKita, 1980, WaKita and Kobayashi 1980a, b) described the same situation in the dog and proposed that the orientation of the S-face of the Tomes' processes is related to the nature of the Hunter-Schreger bands. In such cases the row of cross sectioned prisms will appear parallel to each other (BoyDE's pattern 2, 1965). This represented in figure 11 . This scheme suggests that the variation in prism pattern is due to differences in the orientation of the S-faces. Therefore, prism pattern might not be an entirely reliable taxonomic criterion. The shapes and sizes of the prisms should also be taken into consideration. Recently Kozawa (1978) showed that prism arrangement as well as size and shape were useful parameters in his study of Proboscidean evolution.

Acknowledgements. The authors would like to thank Mr. K. TAKeuchi and Mr. M. Hoshino of our department for their excellent technical assistance, and Miss K. RAscheR of the Institut für Anatomie I, Ruhr-Universität Bochum, Germany, for correction of the English manuscript. We are 
also indebted to the Nissei Sangyo Inc. for making available facilities for using the scanning electron microscope, Hitachi S-430.

\section{ネコのトームスの突起の立体形態と エナメル小柱形成に関する研究}

脇田 稔, 土屋 博, 郡司位秀, 小林茂夫

エナメル質の微細構造の形態発生を究明するために，ネコのエナメル芽細胞のトームスの 突起を透過および走査電子顕微鏡で観察し，その三次元形態を示した。トームスの突起ほ 一般的に，斜めに切り取られた円柱の角と表現され得る，この突起は，歯頸側を向く半月 形の平面（ $\mathrm{S}$ 面）と，咬頭側に向いている半月形の曲面（N面）によって構成されてい る. $\mathrm{S}$ 面の歯頸側の辺縁部は，歯頸側に隣接するエナメル芽細胞の自由表面に移行してい る. エナメル質を形成し，エナメル小柱内のアパタイト結晶の配列を決定するのは，トー ムスの突起の S 面とその歯頸側に連続するエナメル芽細胞の自由表面のみであり，小柱内 の結晶配列は，結晶がトームスの突起の $\mathrm{S}$ 面とエナメル芽細胞自由表面に対して，直角に 配列することによって行なわれる，従って，エナメル小柱内の結晶配列およびエナメル 質の中での小柱の配列は，トームスの突起の三次元的形態によって決定される。これらの トームスの突起の立体的形態は 模式図によって示され，これと切片標本でみられる微細 構造との関係が討論された。

\section{REFERENCES}

Allan, J. H.: Maturation of enamel. In: (ed. by) A. E. W. Miles: Structural and chemical organization of teeth. Academic Press, New York-London, 1967 (Vol. II, p. 467-494).

Bale, W. F., H. C. Hodge and S. L. Warren: Roentogen-ray diffraction studies of enamel and dentine. Amer. J. Roentogenol. 32: 369-376 (1934).

Boyde, A.: The structure of developing mammalian dental enamel. In: (ed. by) M. V. Stack and R. W. Fearnhead: Tooth enamel. John Wright \& Son Ltd., Bristol, 1965 (p. 163-167).

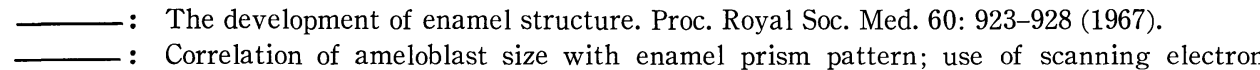
microscope to make surface area measurement. Z. Zellforsch. 93: 583-593 (1969).

- Comparative histology of mammalian teeth. In: (ed. by) A. A. Dahlberg: Dental morphology and evolution. The University of Chicago Press, Chicago, 1971 (p. 81-94).

Dietrich, H. F. and A. R. Fontaine : A decalcification method for ultrastructure of echinoderm tissues. Stain Technol. 50: 351-354 (1975).

Fearnhead, R. W.: Preparation of ultrathin sections of mineralized human enamel. Nature (Lond.) 185: 550-551 (1960).

Frank, R. M. and R. F. Sognnaes : Electron microscopy of matrix formation and calcification in rat enamel. Arch. oral Biol. 1: 339-348 (1960).

Frank, R. M. and J. Nalbandian : Ultrastructure of amelogenesis. In: (ed. by) A. E. W. Miles: Structural and chemical organization of teeth. Academic Press, New York-London, 1967. (Vol. I, p. 399-466).

Fujita, T.: Histology of teeth. (In Japanese). Ishiyaku Press, Tokyo, 1957. 
Gerould, C. H.: Ultramicrostructure of the human tooth as revealed by the electron microscope. J. dent. Res. 23: 239-245 (1944).

Helmcke, J.-G.: Bau und Struktur der Zahnhartsubstanzen. Ergebnisse licht-, polarisations- und elektronenmikroskopischer Forschung. Deut. zahnärztl. Z. 15: 155-168 (1960).

- : Ultrastructure of enamel. In: (ed. by) A. E. W. Miles: Structural and chemical organization of teeth. Academic Press, New York-London, 1967 (Vol. II, p. 135-163).

Helmcke, J.-G., L. Schulz and D. B. Scott: Querstreifung der menschlicheri Schmelzprismen. Deut. zahnärztl. Z. 18: 569-575, 626-637 (1963).

Kallenbach, E.: Fine structure of secretory ameloblasts in the kitten. Amer. J. Anat. 148: 479512 (1977).

Kirino, T., T. Ichijo, M. Goto, T. Ono, Y. Kozawa, Y. Yamashita, M. Wakita and S. Suzuki : Studies on the structure of human enamel by scanning electron microscopy; 1 . On the form of enamel prism, prism sheath, and interprismatic substance. (In Japanese). J. Stomatol. Soc. Jap. 39: 247-296 (1972).

Kozawa, Y.: Comparative histology of Proboscidean molar enamel. J. Stomatol. Soc. Jap. 45: 585-606 (1978).

Lenz, H.: Elektronenmikroskopische Untersuchungen der Schmelzgenese. Deut. zahnärztl. Z. 13: 991-1005 (1958).

Lyon, D. G. and A. I. Darling: Orientation of the crystallites in human dental enamel. Brit. dent. J. 102: 483-488 (1957).

Meckel, A. H., W. J. Griebstein and R. J. Neal : Ultrastructure of fully calcified human dental enamel. In: (ed. by) M. V. Stack and R. W. Fearnhead: Tooth enamel. John Wright \& Son Ltd., Bristol, 1965a (p. 160-162).

: Structure of mature human dental enamel as observed by electron microscopy. Arch. oral Biol. 10: 775-783 (1965b).

Poole, D. F. G.: An introduction to the phylogeny of calcified tissues. In: (ed. by) A. A. Dahlberg: Dental morphology and evolution. The University of Chicago Press, Chicago, 1971 (p. 65-79).

Poole, D. F. G. and A. W. Brooks : The arrangement of crystallites in enamel prisms. Arch. oral Biol. 5: 14-24 (1961).

Rönnholm, E.: The amelogenesis of human teeth as revealed by electron microscopy. II. The development of the enamel crystallites. J. Ultrastr. Res. 6: 249-303 (1962).

Schmidt, W. J.: Über die Orientierung der Kristallite im einzelnen Schmelzprisma. Naturwissenschaften 25: 283-284 (1937).

Shobuzawa, M.: Vergleichende Untersuchungen über die Form der Schmelzprismen der Säugetiere. Okajima's Fol. anat. jap. 24: 371-392 (1952).

Skobe, Z.: The secretory stage of amelogenesis in rat mandibular incisor teeth observed by scanning electron microscopy. Calcif. Tiss. Res. 21: 83-103 (1976).

- : Enamel rod formation in the monkey observed by scanning electron microscopy. Anat. Rec. 187: 326-334 (1977).

Wakita, M.: Scanning electron microscopy of the Tomes' processes related to the enamel formation. In: (ed. by) S. Suga: Mechanism of enamel formation; Report to the Grant of the Japanese Ministry of Education (Private publication), 1980 (p. 72-75).

Wakita, M. and S. Kobayashi : On the three dimentional structure of Tomes' processes and development of fine structure of enamel in the dog. Acta anat. nippon. 55: 378-379 (1980a).

- : Studies on the three dimentional structure of the Tomes' process and enamel formation; special reference to the morphogenesis of the prism sheath. Jap. J. oral Biol. 22 (Suppl.); 155 (1980b).

Weber, D. F. and P. L. Glick : Correlative microscopy of enamel prism orientation. Amer. J. Anat. 144: 407-420 (1975).

朌田稔

下951 新潟市学校町通り二番町 5274

新潟大学䊝学部

门腔解剖学第二教筈
Dr. Minoru Wakita

Department of Oral Anatomy II

Niigata University School of Dentistry

Niigata, 951 Japan 